\title{
IAMJ
}

INTERNATIONAL

AYURVEDIC

MEDICAL JOURNAL

\section{CO-RELATION BETWEEN DEHA PRAKRITI AND BLOOD GROUP IN HEALTHY INDIVIDUALS}

\section{$\underline{\text { Suman Meena }}^{1}$, Pradeep Kumar Meena ${ }^{2}$, Vidula Gujjarwar ${ }^{3}$}

${ }^{1}$ BAMS, MD, Rog Nidana Evum Vikriti Vigyan, Ch. Brahm Prakash Ayurved Charak Sansthan, khera dabar, New Delhi, India

${ }^{2}$ Lecturer, Dept. of Kaya Chikitsha, M.M.M, Govt. Ayurved college, Udaipur, Rajasthan, India

${ }^{3}$ HOD \& Professor, PG Department of Rog Nidana Evum Vikriti Vigyan, Ch. Brahm Prakash Ayurved Charak Sansthan, Khera Dabar, New Delhi, India

Corresponding Author: dr.pradeepjareda@gmail.com

https://doi.org/10.46607/iamj0109042021

(Published online: April 2021)

Open Access

(C) International Ayurvedic Medical Journal, India 2021

Article Received: 24/03/2021 - Peer Reviewed: 31/03/2021 - Accepted for Publication: 01/04/2021

Check for updates

\section{ABSTRACT}

Introduction: Prakriti stands for nature of the body in terms of Dosha and is decided at the time of conception according to the predominance of Dosha. According to Ayurvedic Acharyas, Prakriti of an individual cannot change during his whole life, same as blood group of an individual does not change during his life. In the present study, a relationship between Deha Prakriti and Blood Group was established. Aim and Objective: The aim of the study is to find an association between Deha Prakriti and Blood group in healthy individual. Material and Methods: For this study to be carried out, a total of 150 healthy individual (50 of each dominant prakriti) were selected. Assessment of Prakriti was done using K. Patwardhan and R. Sharma, "Prakriti: a self-assessment questionnaire" and Blood group sample was taken and investigations were carried out in pathology lab, Ch. Brahm Prakash Ayurved Charak Sansthan, Khera Dabar, Najafgarh, New Delhi and A one-way repeated measures ANOVA also known as a within-subjects ANOVA was applied to test the association between Deha prakriti and Blood group in healthy individual. Results The prevalence of different blood group as found in our study is in the order of $\mathrm{B}+, \mathrm{O}+, \mathrm{A}+, \mathrm{AB}+, \mathrm{A}-, \mathrm{AB}-, \mathrm{B}-$ and $\mathrm{O}-$ respectively. On analyzing the blood group with 
respect to Prakriti types, association was noticed between blood group type B with all single Doshaj Prakriti (Vataj, Pittaj and Kaphaj). This study shows that blood groups cannot be thus used as features to classify dominant Prakriti as no statistically significant association was found between them $(\mathrm{p}>0.05)$.

Keywords: Blood group, Prakriti, Vata, Pitta, Kapha.

\section{INTRODUCTION}

Ayurveda is an eternal science with absolute principles, Prakriti is one of them. Prakriti stands for nature of the body in terms of Dosha and is decided at the time of conception according to the predominance of Dosha ${ }^{l}$. It does not change during the whole life and is responsible for the physical and mental characters of an individual. According to Ayurveda some people have same disease, but their management is of different types according difference in the Doshaj Prakriti. Acharya Charak has mentioned seven types of Prakriti on the basis of involvement of Tridosha ${ }^{2}$.

In Ayurveda, three main Dosha are described Vata, Pitta, and Kapha. According to Ashtang

Hridaya, the properties of Vata Dosha are Ruksha, Laghu, Sheeta, Khara, Suksham, Chala, which produce different characteristics of Vataja Prakriti. In the same way properties of Pitta Dosha are Sneha, Tikshna, Ushna, Laghu, Visra, Saram, Drava and the properties of Kapha Dosha are Snigdha, Sheeta, Guru, Manda, Slaksna, Mrtsan, Sthira respectively produce different characteristic of Pittaja and Kaphaja Prakriti ${ }^{3}$. These Prakriti display basic physiological characters of an individual and also it plays role in prognosis of the disease. Prakriti or physical constitution of the foetus is determined by

1. Nature of Sukhra and Shonita.

2. Seasons and condition of the uterus.

3. Food and regimens of the mother; and

4. Nature of the Mahabhutas comprising the foetus ${ }^{4}$.

Seven kinds of Prakriti (constitution of the body) get formed such as by involvement of each Dosha separately, by the combination of two Dosha and by combination of all the Dosha. Whichever the Dosha that is predominant at the time of union of Sukhra (semen/spermatozoa) and Shonita (ovum) the Prakriti of the person gets formed from that particular Dosha ${ }^{5}$. These features of constitutions of men, will neither increase, change otherwise, nor decrease naturally (of their own accord); they do so, only in a dyeing person. Just as insects born in poison are not killed by that poison, similarly the constitutions will not be able to harm the person ${ }^{6}$. According to Ayurvedic Acharyas, Prakriti of an individual cannot change during his whole life, same as blood group of an individual does not change during his life.

Blood Groups are decided by protein molecules present on the surface of RBCs. When blood from two individual is mixed, sometimes clumping i.e. agglutination occurs. This clumping is because of the immunological reactions which is antigenantibody reaction. But, why clumping occurs in some cases and not in other cases remained a mystery until the discovery of blood groups by the Austrian Scientist Karl Landsteiner in 1901. Rh factor is an antigen present in RBC. This antigen was discovered by Landsteiner and Wiener. It was first discovered in rhesus monkey, so it was named as $\mathrm{Rh}$ factor. There are many $\mathrm{Rh}$ antigens but only the $\mathrm{D}$ is more antigenic in humans ${ }^{7}$. There is certain relation between parents and inborn child in blood grouping. The heredity gene is directly concern with the inborn child's metabolic pattern too. The hereditary metabolic pattern of an individual is the continuation of metabolic pattern of the parents. So, these relations according to modern findings are due to gene. But around thousands of years ago the word called "gene was not used. In fact, the Pitrij bhav (Father's character) and Matrij Bhav (Mother's character) refer to gene $\mathrm{XY}$ and $\mathrm{XX}$ respectively, it is not so direct but pointing towards these genes. 
Still rediscovery of Prakriti is not there in modern techniques $^{8}$. As Deha Prakriti is formed at the time of conception so there may be a strong relationship between Deha Prakriti and Blood Group, as blood group is also derived from paternal and maternal part. In the present study will be tried to develop a relationship between Deha Prakriti and Blood Group.

Material And Methods: A total 150 healthy individual (50 of each dominant prakriti) were randomly selected for the study from $\mathrm{Ch}$. Brahm Prakash Ayurved Charak Sansthan, Khera Dabar, Najafgarh, New Delhi after getting written informed consent from the individual, and obtaining Ethical committee approval, IEC Code. 2018/3/MD/13 and A one-way repeated measures Anova also known as a within-subjects Anova was applied to test the association between Deha Prakriti and Blood group in healthy individual.

\section{Assessment of Prakriti}

Charak Samhita explained the specific attributes of a particular Dosha along with the description of the specific features these attributes produce in an individual. Thus, Vata, Pitta and Kapha have been assigned with eight, five and twelve Gunas respectively. Each Guna produces one or more observable characters at the physical, physiological, or psychological domains. This questionnaire is designed in such a way that, each feature as described in Charak Samhita Vimana Sthana has been converted into a simple question/statement. The applicants were required to record their agreement or disagreement with the statement/question in a column provided for the purpose in the form of "yes" or "no". The scores to be allotted for a particular type of response was specified against the statement in a separate column ${ }^{9}$.

The mathematical model in this questionnaire is based on the "Guna" principle of Ayurveda. The percentage superiority of a Dosha in an individual was calculated on the basis of the total scores obtained for each Dosha by simple mathematical calculation as shown in: $\underline{\text { Total score scored by an individual for a Dosha }}$ $\times 100$

Total scores allotted to that Dosha

Assessment of Blood Group: Sample was collected from person and after collection blood group was decided on the basic of slide method by observing agglutination reaction between sample and reagent.

\section{Observation and Results:}

A total of 150 subjects were included in the final analysis.

1. Among the study population, 71(47.33\%) participants were male and remaining 79 (52.67\%) participants were female.

2. Among the study population, 72 (48\%) participants were belongs to Hemant season, 42(38\%) participants were belongs to Sharad season, 35 (23\%) participants were belongs to Shishir season and $1(0.67 \%)$ participants were belongs to Varsha season.

3. Among the study population, 50 (33\%) participants were belongs to Kapha dominant Prakriti, 50 (33\%) participants were belongs to Pitta dominant Prakriti, 50 (33\%) participants were belongs to Kapha dominant Prakriti.

4. Among the study population, 145 (96.67\%) participants were belongs to $\mathrm{Rh}+\mathrm{ve}$ Factor and $5(3.33 \%)$ participants were belongs to $\mathrm{Rh}-\mathrm{ve}$ Factor.

5. Among the study population, 2(1.33\%) participants were belongs to A- blood group, $20(13.33 \%)$ participants were belongs to $\mathrm{A}+$ blood group, $1(0.67 \%)$ participants belongs to B- blood group, 62(41.33\%) participants belongs to $\mathrm{B}+$ blood group, $2(1.33 \%)$ participants belongs to AB- blood group, 16(10.67\%) participants belongs to $\mathrm{AB}+$ blood group, remaining $47 \quad(31.33 \%)$ participants were belongs to $\mathrm{O}+$ blood group and $\mathrm{O}$ - group not found in population. (Table- 1) 
Table 1: Descriptive analysis of blood group in the study population $(\mathrm{N}=150)$

\begin{tabular}{|l|l|l|}
\hline Blood Group & Frequency & Percentages \\
\hline A- & 2 & $1.33 \%$ \\
\hline A+ & 20 & $13.33 \%$ \\
\hline B- & 1 & $0.67 \%$ \\
\hline B+ & 62 & $41.33 \%$ \\
\hline AB- & 2 & $1.33 \%$ \\
\hline AB+ & 16 & $10.67 \%$ \\
\hline O- & 0 & $0 \%$ \\
\hline O+ & 47 & $31.33 \%$ \\
\hline
\end{tabular}

- Out of 50 Vataj Prakriti 17(34\%) participants were belongs to $\mathrm{O}+$ Blood Group, 5(10\%) were belongs to A+ Blood Group, 21(42\%) were belongs to B+ Blood Group, $6(12 \%)$ were belongs to $\mathrm{AB}+$ Blood Group, remaining $1(2 \%)$ were belongs to $\mathrm{AB}$ - Blood Group and A-, B-, O- Blood Group were not found in Vataj Prakriti population. (Table 2)

Table 2: Descriptive analysis of blood group in Vata dominant Prakriti $(\mathrm{N}=50)$

\begin{tabular}{|l|l|l|l|}
\hline Serial no. & Blood Group & Vataj Prakriti & Percentage \\
\hline 1. & O+ve & 17 & $34 \%$ \\
\hline 2. & A+ve & 5 & $10 \%$ \\
\hline 3. & B+ve & 21 & $42 \%$ \\
\hline 4. & AB+ve & 6 & $12 \%$ \\
\hline 5. & O-ve & 0 & $0 \%$ \\
\hline 6. & A-ve & 0 & $0 \%$ \\
\hline 7. & B-ve & 0 & $0 \%$ \\
\hline 8. & AB-ve & 1 & $2 \%$ \\
\hline 9. & Total & 50 & $100 \%$ \\
\hline
\end{tabular}

- Out of 50 Pittaj Prakriti 15(30\%) participants were belongs to $\mathrm{O}+$ Blood Group, 4(8\%) were belongs to A+ Blood Group, 24(48\%) were belongs to B+ Blood Group, 4(8\%) were belongs to $\mathrm{AB}+$ Blood Group,
1(2\%) were belongs to A- Blood Group, 1(2\%) were belongs to B- Blood Group, remaining 1(2\%) were belongs to AB- Blood Group and O- Blood Group were not found in Pittaj Prakriti population.(Table 3)

Table 3: Descriptive analysis of blood group in Pitta dominant Prakriti (N=50)

\begin{tabular}{|l|l|l|l|}
\hline Serial no. & Blood Group & Pittaj Prakriti & Percentage \\
\hline 1. & O+ve & 15 & $30 \%$ \\
\hline 2. & A+ve & 4 & $8 \%$ \\
\hline 3. & B + ve & 24 & $48 \%$ \\
\hline 4. & AB+ve & 4 & $8 \%$ \\
\hline 5. & O-ve & 0 & $0 \%$ \\
\hline 6. & A-ve & 1 & $2 \%$ \\
\hline 7. & B-ve & 1 & $2 \%$ \\
\hline 8. & AB-ve & 1 & $2 \%$ \\
\hline 9. & Total & 50 & $100 \%$ \\
\hline
\end{tabular}

- $\quad$ Out of 50 Kaphaj Prakriti $15 \quad(30 \%)$ participants were belongs to $\mathrm{O}+$ Blood Group, 11(22\%) were belongs to A+ Blood Group, 17(34\%) were belongs to $\mathrm{B}+$ Blood Group, 6(12\%) were belongs to $\mathrm{AB}+$ Blood Group, remaining $1(2 \%)$ were belongs to A- Blood Group and B-, AB-, O- Blood Group were not found in Kaphaj Prakriti population (Table 4) 
Table 4: Descriptive analysis of blood group in Kapha dominant Prakriti (N=50)

\begin{tabular}{|l|l|l|l|}
\hline \multicolumn{1}{|c|}{ Serial no. } & Blood Group & Kaphaj Prakriti & Percentage \\
\hline 1. & O+ve & 15 & $30 \%$ \\
\hline 2. & A+ve & 11 & $22 \%$ \\
\hline 3. & B+ve & 17 & $34 \%$ \\
\hline 4. & AB+ve & 6 & $12 \%$ \\
\hline 5. & O-ve & 0 & $0 \%$ \\
\hline 6. & A-ve & 1 & $2 \%$ \\
\hline 7. & B-ve & 0 & $0 \%$ \\
\hline 8. & AB-ve & 0 & $0 \%$ \\
\hline 9. & Total & 50 & $100 \%$ \\
\hline
\end{tabular}

Table 5: Inter group comparison of blood group across dominant Prakriti (one-way repeated measures ANOVA) $(\mathrm{N}=150)$

\begin{tabular}{|c|c|c|c|c|c|c|}
\hline \multirow[t]{2}{*}{ Blood Group } & \multicolumn{3}{|c|}{ Dominant Prakriti } & \multirow[b]{2}{*}{ F (DFn, DFd) } & \multirow[t]{2}{*}{$P$ value } & \multirow[t]{2}{*}{ DF } \\
\hline & Kapha & Pitta & Vata & & & \\
\hline A- & 1 & 1 & 0 & \multirow[t]{8}{*}{1} & \multirow[t]{8}{*}{0.3637} & \multirow{8}{*}{2} \\
\hline $\mathrm{A}+$ & 11 & 4 & 5 & & & \\
\hline $\mathrm{Ab}-$ & 0 & 1 & 1 & & & \\
\hline $\mathrm{Ab}+$ & 6 & 4 & 6 & & & \\
\hline B- & 0 & 1 & 0 & & & \\
\hline $\mathrm{B}+$ & 17 & 24 & 21 & & & \\
\hline $\mathrm{O}-$ & 0 & 0 & 0 & & & \\
\hline $\mathrm{O}+$ & 15 & 15 & 17 & & & \\
\hline
\end{tabular}

$P$ value $=0.3637$

If $\mathrm{P}$ value is $>0.05$ then result will be insignificant. So, there is no co-relation between Deha Prakriti and blood group.

\section{DISCUSSION}

The critical analysis of observed results based on Ayurvedic Siddhantha \& scientific thoughts are described under this part.

- Among the study population, 2(1.33\%) participants were belongs to A- blood group, 20 (13.33\%) participants were belongs to $\mathrm{A}+$ blood group, $1(0.67 \%)$ participants belongs to B- blood group, $62(41.33 \%)$ participants belongs to $\mathrm{B}+$ blood group, $2(1.33 \%)$ participants belongs to $\mathrm{AB}$ - blood group, $16(10.67 \%)$ participants belongs to $\mathrm{AB}+$ blood group, and remaining 47 (31.33\%) participants were belongs to $\mathrm{O}+$ blood group

- The prevalence of different blood group as found in our study is in the order of $\mathrm{B}+, \mathrm{O}+, \mathrm{A}+$, $\mathrm{AB}+, \mathrm{A}-, \mathrm{AB}-, \mathrm{B}-$ and $\mathrm{O}-$ respectively. On analyzing the blood group with respect to Prakriti types, association was noticed between blood group type B with all single Doshaj Prakriti (Vataj, Pittaj and
Kaphaj). May be some variations found in Dwandaja Prakriti and Sannipathik Prakriti because in present study only single Doshaj Prakriti is taken.

- The frequencies of blood groups vary with geographical areas, and even small variations may be seen in different areas of a small country reflecting the ethnic and genetic diversity occurring within population. For example, the most common blood groups as reported in Australians are $\mathrm{O}$ and $\mathrm{A}$ while in Africans B group. On the other side, the blood group $\mathrm{O}$ and $\mathrm{A}$ are most prevalent group in people of Egypt and Russian Federation, respectively. Similar studies from South India showed that blood group $\mathrm{O}$ was most common $(38.75 \%)$ blood group, followed by group B (32.69\%), group A (18.85\%), and AB (5.27\%). Similarly, Karnataka and Jammu and Kashmir appeared blood group $\mathrm{O}$ as the most common type.

- This study shows that blood groups cannot be thus used as features to classify dominant Prakriti as 
no statistically significant association was found between them $(p>0.05)$.

- Blood group does not decide Deha Prakriti instead Deha Prakriti (constitution) of body and blood group of persons decided by chromosomes so there (in chromosomal study) must be some relation is found between them.

- During the selection of Prakriti, Pitta Prakriti was found to be predominant among the sample population. But I took $50-50$ individual of each Prakriti due to restriction of inclusion criteria. The reason of the dominance of specific Dosha in the sample population can be further scientifically investigated considering the fact that Prakriti of an individual depends on various factors like: heredity, maternal diet, and lifestyle. Dosha dominance in the maternal reproductive tract, place of birth, time of birth, age of parents, socio-economic condition, tropical region, spicy food, cause of high pollution etc. This can further widen the scope of this study, which may yield new and valuable knowledge.

\section{CONCLUSION}

A final conclusion is a theory, which is reached after considering the evidence, arguments or premises. Their presence is common in academic or research work. In research and experimentation, conclusions are determinations made by studying the results of previous work and practice is the science that studies the rules and procedures to distinguish correct reasoning (valid) or incorrect (invalid). It is the part that the reader may remember most. In the present study, an attempt has been made to the association of A B O blood group with the Prakriti predominant doshas in healthy individual. We find that maximum number of individuals has $\mathrm{B}+$ blood group and secondly $\mathrm{O}+$ and least were $\mathrm{O}-$ blood group. This study shows that blood groups cannot be thus used as features to classify dominant Prakriti as no statistically significant association was found between them $(p>0.05)$.

\section{REFERENCES}

1. Murthy KRS, editor. Sushrut Samhita. Vol.1. Varanasi: Chaukhambha Orientalia; Reprint 2012. p. 70.

2. Sharma RK, Dash VB, editors. Agnivesa's Charak samhita. Vol.1. Varanasi: Chowkhambha Sanskrit Series Office; Reprint 2012. p. 154.

3. Murthy KRS, editor. Vagbhata's Asthanga Hrdayam. Vol.1. Varanasi: Chowkhamba Krishnnadas Academy; Reprint 2013. p.8.

4. Sharma RK, Dash VB, editors. Agnivesa's Charak samhita. Vol.1. Varanasi: Chowkhambha Sanskrit Series Office; Reprint 2013. p. 262.

5. Murthy KRS, editor. Sushrut Samhita. Vol.1. Varanasi: Chaukhambha Orientalia; Reprint 2012. p. 70.

6. Murthy KRS, editor. Sushrut Samhita. Vol.1. Varanasi: Chaukhambha Orientalia; Reprint 2012. p. 73.

7. Sembulingam K, Sembulingam P. Essentials of Medical Physiology. 5thed. New Delhi: Jaypee Brothers Medical Publishers (P) Ltd; Reprint 2010. p. 129,133 .

8. Chaple J, Dawale A. Relation between prakriti and blood group among ayurvedic students. UJAHM [Internet]. 2016Apr [cited 2018 March 20]; p. 18-20. Available from: www.ujconline.net

9. K. Patwardhan and R. Sharma, "Prakriti: a selfassessment questionnaire", Journal of All India Sharir Research Institute, Vol. 1, No. 5, PP 11-16, 2005

\section{Source of Support: Nil \\ Conflict of Interest: None Declared}

How to cite this URL: Suman Meena et al: Co Relation Between Deha Prakriti And Blood Group In Healthy Individuals. International Ayurvedic Medical Journal \{online\} 2021 cited April, 2021\} Available from: http://www.iamj.in/posts/images/upload/696_702.pdf 